\title{
Tatalaksana Terkini Demam pada Anak
}

\author{
Carlson $^{1}$, Bella Kurnia ${ }^{1}$, Ariani Dewi Widodo ${ }^{2}$ \\ ${ }^{1}$ Mahasiswa Fakultas Kedokteran Universitas Kristen Krida Wacana \\ ${ }^{2}$ Staf Rumah Sakit Anak dan Bunda Harapan Kita \\ Alamat Korespondensi : carlson.renovatio@gmail.com
}

\begin{abstract}
Abstrak
Demam merupakan sebuah proses alamiah yang timbul sebagai mekanisme pertahanan tubuh terhadap patogen, namun terkadang suhu yang terlalu tinggi seringkali menjadi suatu dilema sendiri yang menimbulkan kekhawatiran pada orangtua. Demam terjadi karena peningkatan pusat pengatur suhu di hipotalamus yang dipengaruhi oleh Interleukin-1 (IL-1). Terdapat berbagai variasi kisaran suhu normal pada anak menurut tempat pengukurannya. Tatalaksana demam yang terutama yaitu pemberian antipiretik seperti parasetamol atau ibuprofen. Beberapa studi menemukan bahwa penggunaan metode kombinasi antipiretik memberikan efek antipiretik yang lebih tinggi, namun hal ini belum dapat direkomendasikan karena belum ada studi mengenai keamanannya. Metode kompres hangat juga dapat diberikan sebagai terapi tambahan untuk membantu menurunkan demam pada anak. Penggunaan antipiretik sesuai dosis yang direkomendasikan ditambah dengan kompres hangat sudah terbukti lebih efektif untuk menurunkan demam pada anak terutama di 30 menit pertama.
\end{abstract}

Kata Kunci : Demam, Interleukin-1, Kompres, Tepid Sponging

\section{Update on Fever Management in Children}

\begin{abstract}
Fever is a natural process that occurs as a defense mechanism to a pathogen, but sometimes high fever can be a problem and making the parents worried about their children. Fever occurs due to an increase in the temperature control center in the hypothalamus, which is affected by Interleukin-1, a potent endogenous pyrogen. There are some variation of temperature range in children depends on the site where the measurement was taken. The main treatment of fever in children is the use of antipyretic agent such as paracetamol/acetaminophen or ibuprofen. Some studies showed that the use of combination method will give a better and significant results, but until now this method still not recommended in daily practice because of lack of evidence for its safety. Tepid sponging can be given as an adjuvant therapy to reduce the fever in children. The use of proper dose of antipyretic combined with non-pharmacology therapies such as tepid sponging is proven more effective to reduce fever in children especially the first 30 minutes.
\end{abstract}

Keywords : Fever, Interleukin-1, Tepid Sponging

\section{Pendahuluan}

Kasus demam pada anak merupakan kasus atau gejala yang paling sering ditemui pada praktek sehari-hari. Demam merupakan sebuah proses alamiah yang timbul sebagai mekanisme pertahanan tubuh terhadap patogen, namun terkadang suhu yang terlalu tinggi seringkali menjadi suatu dilema sendiri yang menimbulkan kekhawatiran pada
orangtua.

Kesalahan tersering orangtua yaitu ingin dengan cepat menurunkan suhu anaknya yang sedang demam ke rentang suhu normal. Kebanyakan orang tua memberikan obat penurun panas pada anak mereka walau belum ada indikasi yang tepat untuk pemberian obat. $^{1,2}$ 
Sekitar $50 \%$ orang tua menganggap suhu kurang dari $<38^{\circ} \mathrm{C}$ sebagai demam, dan $25 \%$ dari tenaga kesehatan memberikan obat penurun panas untuk suhu $<37,8^{\circ} \mathrm{C}$. Bahkan sebanyak $50 \%$ orangtua memberikan obat penurun panas dengan dosis yang salah. Tenaga kesehatan memiliki tanggung jawab untuk memberikan edukasi kepada orangtua tentang demam dan waktu yang tepat untuk pemberian obat penurun panas. ${ }^{1-3}$

Salah persepsi tentang ambang batas suhu normal anak seringkali menjadi penyebab overtreatment pada kasus demam pada anak. Ketakutan ini dikenal juga dengan istilah fever phobia, karena seringkali para orang tua terlalu khawatir dengan akibat buruk dari sebuah demam yang tidak tertangani dengan baik seperti kejang, kerusakan otak, dan sebagainya. ${ }^{3}$

\section{Definisi Demam dan Pirogen}

Pengaturan suhu tubuh manusia merupakan hasil dari keseimbangan antara produksi dan pelepasan panas. Demam adalah keadaan suhu tubuh di atas normal sebagai akibat peningkatan pusat pengatur suhu di hipotalamus yang dipengaruhi oleh interleukin-1 (IL-1). Demam merupakan respons fisiologis dan dapat dikatakan demam apabila bila suhu tubuh $\geq 38^{\circ} \mathrm{C}$. 4,5

Pirogen adalah suatu zat yang menyebabkan demam, bisa merupakan pirogen endogen maupun eksogen. Pirogen endogen seperti yang kita ketahui seperti IL-1, Tumor Necrosis Factor dan Interferon (IFN). Sedangkan pirogen eksogen didapat dari luar yang berkemampuan merangsang IL-1, pirogen eksogen bisa berupa pirogen mikrobial dan pirogen non mikrobial. ${ }^{5}$

\section{Variasi Suhu Normal dan Pengukuran Suhu Tubuh}

Pengukuran suhu tubuh sangat dipengaruhi oleh metabolisme tubuh dan aliran darah, dan hasil pengukuran akan sangat berbeda sesuai dengan tempat pengukuran. Pengukuran suhu tubuh secara umum dapat dilakukan di rektal, oral, aksila, dan membran timpani. ${ }^{6}$

Pengukuran suhu rektal sudah menjadi baku emas untuk pengukuran suhu sampai sekarang ini, tetapi beberapa studi menemukan keterbatasan dari metode ini. Suhu rektal cenderung tidak mudah berubah-ubah dibandingkan dengan suhu badan (core temperature). Pengukuran suhu rektal juga dipengaruhi oleh beberapa faktor seperti kedalaman pengukuran, sirkulasi darah dan adanya feses. Pengukuran ini akan menimbulkan ketidaknyamanan untuk anak dan memicu kekhawatiran ibu, meningkatkan risiko infeksi, dan juga memiliki risiko perforasi rektum. ${ }^{6}$

Pengukuran suhu aksila sangat mudah dilakukan dibandingkan pengukuran suhu rektal. Beberapa studi mengemukakan bahwa pengukuran suhu aksila memiliki perkiraan yang kurang akurat terhadap suhu tubuh (core temperature) anak. Pengukuran ini sangat dipengaruhi oleh banyak faktor seperti faktor kondisi lingkungan. Walau memiliki sensitivitas dan spesifisitas yang rendah, pengukuran suhu aksila direkomendasikan oleh American Academy of Pediatrics sebagai pemeriksaan awal (screening) terutama untuk neonatus, karena dengan pengukuran suhu rektal ada risiko untuk terjadinya perforasi rektum. ${ }^{6}$

Pengukuran suhu oral sangat mudah dilakukan dan menunjukkan temperatur dari arteri lingualis. Akan tetapi, pengukuran ini sangat dipengaruhi oleh konsumsi makanan ataupun minuman terakhir. Pengukuran ini juga memerlukan penempatan sensor termometer sublingual sekitar 3-4 menit, dimana hal ini sulit untuk dilakukan bagi anak yang masih kecil. Penggunaan suhu oral akan lebih akurat apabila dilakukan pada anak yang lebih besar. ${ }^{6}$

Studi terdahulu menunjukkan bahwa pengukuran suhu dari membran timpani lebih akurat dalam menunjukkan suhu tubuh yang sebenarnya dibandingkan dengan pengukuran pada rektal, tetapi alat ukurnya kurang praktis untuk dipakai dalam praktik sehari-hari. Termometer membran timpani yang modern sekarang mengukur radiasi panas dari membran timpani dan saluran telinga, sehingga lebih dikenal sebagai infrared radiation emission detectors (IRED). Sirkulasi pada area membran timpani memiliki suhu yang kurang lebih sama dengan area hipotalamus, sehingga bisa dikatakan kalau membran timpani merupakan lokasi yang ideal untuk memperkirakan suhu tubuh yang sebenarnya. Banyak studi mulai membandingkan akurasi pengukuran membran timpani dengan pengukuran lainnya yang 
sudah lazim dilakukan. Banyak yang menemukan variasi suhu yang berbeda-beda, sehingga dapat disimpulkan bahwa tidak direkomendasikan menggunakan satu metode sebagai standar pemeriksaan karena rentan terjadi kesalahan interpretasi. ${ }^{6}$

Beberapa faktor fisiologis yang mempengaruhi suhu tubuh adalah waktu pengukuran (suhu tubuh pagi hari berbeda dengan saat sore hari), tingkatan aktivitas, makanan, usia (bayi dan anak yang lebih muda umumnya memiliki suhu yang lebih tinggi daripada anak yang lebih besar), dan siklus menstruasi (suhu tubuh lebih tinggi sekitar 0,4 derajat pada fase luteal dibandingkan dengan fase folikuler). Kisaran suhu normal dapat dilihat pada tabel 1.

\section{Tabel 1. Kisaran Suhu Normal Menurut Tempat Pengukurannya ${ }^{6}$}

\begin{tabular}{ll}
\hline Tempat Pengukuran & Kisaran Suhu Normal \\
\hline Rektal & $36,6^{\circ} \mathrm{C}-38^{\circ} \mathrm{C}\left(97,9^{\circ} \mathrm{F}-100,4^{\circ} \mathrm{F}\right)$ \\
Telinga & $35,8^{\circ} \mathrm{C}-38^{\circ} \mathrm{C}\left(96,4^{\circ} \mathrm{F}-100,4^{\circ} \mathrm{F}\right)$ \\
Oral & $35,5^{\circ} \mathrm{C}-37,5^{\circ} \mathrm{C}\left(95,9^{\circ} \mathrm{F}-99,5^{\circ} \mathrm{F}\right)$ \\
Aksial & $36,5^{\circ} \mathrm{C}-37,5^{\circ} \mathrm{C}\left(97,8^{\circ} \mathrm{F}-99,5^{\circ} \mathrm{F}\right)$ \\
\hline
\end{tabular}

\section{Patogenesis Demam dan Termoregulasi}

Termoregulasi adalah sistem dalam tubuh yang mempertahankan suhu tubuh dari pengaruh suhu luar dan berbagai faktor lainnya. Demam merupakan suatu respons tubuh yang terkontrol terhadap suatu keadaan di dalam tubuh dengan meningkatkan suhu tubuh di atas batas normal. ${ }^{5}$

Sistem pengaturan suhu tubuh ini diatur oleh keseimbangan produksi dan pelepasan panas, serta fungsi pusat pengatur suhu di hipotalamus. Tubuh manusia secara alamiah dapat mempertahankan panas dengan vasokonstriksi dan memproduksi panas dengan menggigil. Pada lingkungan panas, pusat pengatur suhu di hipotalamus akan memberikan sinyal untuk melebarkan pembuluh darah, begitu juga sebaliknya. Selain memproduksi panas, tubuh juga dapat melepas panas dengan berbagai cara seperti radiasi, penguapan, konveksi, maupun konduksi. $^{5}$

Demam muncul sebagai suatu hasil dari berbagai macam interaksi biologis seperti virus, bakteri, jamur, kompleks antigenantibodi, dan obat-obatan, yang pada akhirnya akan merangsang pembentukan IL-1.
Komponen ini termasuk juga IL-2, bertanggung jawab atas peningkatan sel $\mathrm{T}$ helper dan memulai produksi prostaglandin di hipotalamus. Sel T-Helper bekerja untuk memberantas infeksi, prostaglandin juga bertanggung jawab dalam menyebabkan demam. Leukosit ketika diaktivasi oleh leukotrien, prostaglandin, dan kalsium, akan melakukan fagositosis terhadap pirogen dan menghasilkan IL-1.,

Daerah spesifik di otak yang mengandung saraf termosensitif disebut juga korpus kalosum lamina terminalis. Saraf ini sensitif terhadap perubahan suhu. IL-1 sudah terbukti menghambat saraf sensitif terhadap hangat dan merangsang saraf yang sensitif terhadap dingin. ${ }^{5}$ Demam merupakan mekanisme fisiologis untuk melawan infeksi. Demam menekan pertumbuhan dan produksi bakteri dan virus, dan menguatkan produksi neutrofil dan proliferasi limfosit T. Sebagian besar demam berlangsung dalam waktu singkat, tidak berbahaya, dan sebenarnya melindungi tubuh penderita. ${ }^{1}$ 


\section{Tata laksana Farmakologis Demam}

Demam pada anak menimbulkan ketakutan sendiri pada orangtua yang seringkali menyebabkan orangtua memberikan antipiretik tanpa mengukur suhu anak terlebih dahulu. Tata laksana demam pada anak secara farmakologis paling sering menggunakan dua macam obat yaitu parasetamol (asetaminofen) dan ibuprofen. ${ }^{1,3}$

Demam pada anak dapat mengubah pola aktivitas, pola tidur, perilaku, dan juga dapat menyebabkan penurunan nafsu makan. Oleh sebab itu, fokus utama dari mengobati demam pada anak sebenarnya adalah untuk membuat anak lebih nyaman dan memperbaiki kualitas hidup anak selama fase akut penyakit masih berlangsung atau selama faktor penyebab demam belum teratasi. ${ }^{1}$

\section{Parasetamol}

Asetaminofen/parasetamol menjadi pilihan setelah ada studi yang menghubungkan antara penggunaan salisilat dengan timbulnya sindroma Reye pada anak. Penggunaan parasetamol dengan dosis $10-15 \mathrm{mg} / \mathrm{kg}$ per dosis setiap 4-6 jam, sudah terbukti aman dan efektif. Onset yang dibutuhkan parasetamol untuk bekerja diperkirakan sekitar 30-60 menit, sekitar $80 \%$ anak akan mengalami penurunan suhu di dalam rentang waktu tersebut (Lihat tabel 2 dan gambar 2). ${ }^{1,8}$

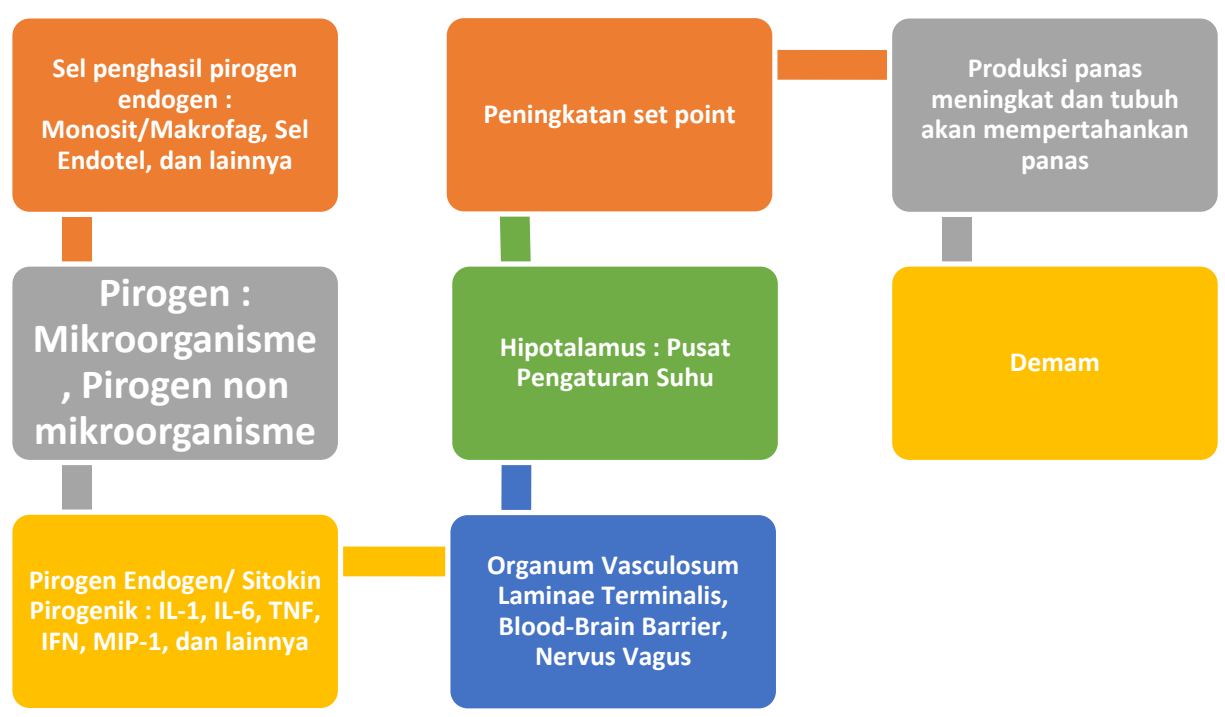

Gambar 1. Patogenesis Demam ${ }^{1,5,7}$

\begin{abstract}
Penggunaan loading dose yang lebih tinggi dalam praktik sehari-hari akan menimbulkan risiko hepatotoksisitas karena kelebihan dosis, sehingga untuk saat ini belum dianjurkan. Walau kasus hepatotoksisitas jarang dilaporkan, akan tetapi hal ini tetap perlu menjadi perhatian bagi kita semua baik tenaga medis maupun orangtua agar berhatihati dalam memberikan obat. Selain hepatotoksisitas, sempat marak studi yang menjelaskan adanya hubungan antara kejadian asma dengan penggunaan parasetamol, tetapi untuk sekarang hal tersebut belum dapat dibuktikan lebih lanjut. ${ }^{1,8}$
\end{abstract}

\section{Ibuprofen}

Meningkatnya penggunaan ibuprofen dalam kasus demam mungkin berkaitan dengan durasi efek obat yang lebih lama. Sudah banyak studi yang membandingkan penggunan ibuprofen dengan parasetamol, tetapi didapatkan hasil yang sangat bervariasi, ada yang mengatakan ibuprofen lebih unggul, tetapi ada juga yang mengatakan efektivitas kedua obat tersebut sama. ${ }^{1}$

Hal yang perlu menjadi perhatian dalam penggunaan ibuprofen adalah kasus gastritis. Seperti kita ketahui ibuprofen merupakan golongan OAINS (obat anti inflamasi non 
steroid), meskipun tidak banyak kasus parah yang dilaporkan akibat penggunaan ibuprofen dengan dosis yang direkomendasikan. Selain kasus perdarahan saluran cerna, ibuprofen juga diketahui mempunyai sifat nefrotoksik, sehingga perlu berhati-hati dalam pemberian kepada anak dengan dehidrasi, gangguan kardiovaskular, penyakit ginjal, maupun obatobatan yang memiliki sifat nefrotoksik. ${ }^{1}$
Ibuprofen juga tidak dianjurkan diberikan pada anak di bawah 6 bulan, karena memiliki farmakokinetik yang berbeda dan karena fungsi ginjal yang belum sempurna. Selain kasus perdarahan saluran cerna dan nefrotoksik, ibuprofen juga pernah dihubungkan dengan infeksi Streptococcus grup $\mathrm{A}$, namun belum ada bukti adekuat untuk mendukung hal ini. ${ }^{1}$

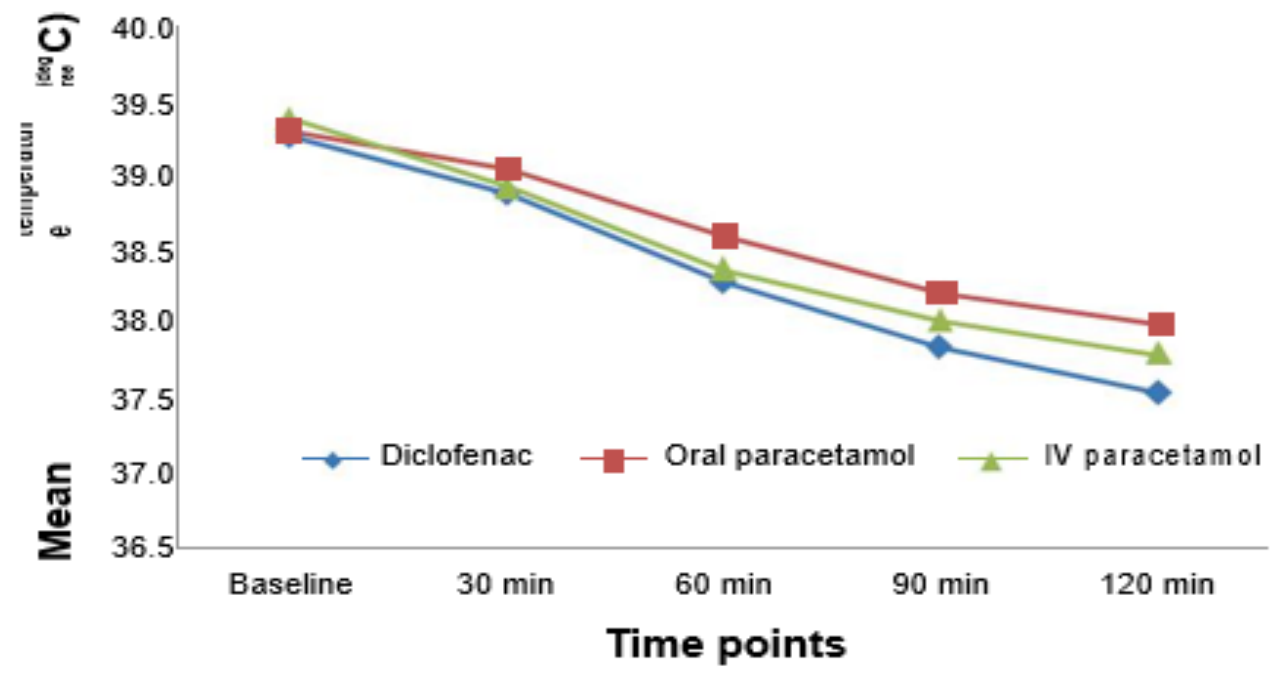

\section{Gambar 2. Perbandingan Pemberian Parasetamol Oral vs Parasetamol IV vs Diklofenak ${ }^{9}$}

Tabel 2. Perbandingan Parasetamol vs Ibuprofen. ${ }^{1}$

\begin{tabular}{ccc}
\hline & Asetaminofen/Parasetamol & Ibuprofen \\
\hline Penurunan Suhu & $1-2^{\circ} \mathrm{C}$ & $1-2^{\circ} \mathrm{C}$ \\
Onset & $<1$ jam & $<1$ jam \\
Peak effect & $3-4$ jam & $3-4$ jam \\
Durasi & $4-6 \mathrm{jam}$ & $6-8 \mathrm{jam}$ \\
Dosis & $10-15 \mathrm{mg} / \mathrm{kg} \mathrm{per} 4 \mathrm{jam}$ & $10 \mathrm{mg} / \mathrm{kg} \mathrm{per} 6 \mathrm{jam}$ \\
Dosis Maksimum Per Hari & $90 \mathrm{mg} / \mathrm{kg}$ & $40 \mathrm{mg} / \mathrm{kg}$ \\
Dosis Maksimum Dewasa & $4 \mathrm{gram}$ & $2,4 \mathrm{gram}$ \\
Usia Rekomendasi & $3 \mathrm{bulan}$ & $6 \mathrm{bulan}$ \\
\hline
\end{tabular}

\section{Parasetamol vs Ibuprofen vs Terapi Kombinasi}

Berbagai studi telah dilakukan untuk membandingkan pemberian antipiretik. Antipiretik dapat diberikan sebagai terapi tunggal (parasetamol saja atau ibuprofen saja), kombinasi (parasetamol+ibuprofen secara bersamaan), maupun kombinasi bergantian (parasetamol kemudian setelah beberapa jam dilanjutkan ibuprofen). 
Pada beberapa studi yang dilakukan, terdapat berbagai hasil yang cukup konsisten mengatakan bahwa terapi kombinasi akan memberikan hasil antipiresis yang lebih baik, khususnya dalam 4-6 jam pertama (dapat dilihat di gambar 3 dan tabel 3). Kombinasi terapi dengan asetaminofen/parasetamol dan ibuprofen memiliki efektivitas yang lebih tinggi untuk menurunkan suhu tubuh dibandingkan dengan terapi tunggal. Walaupun penelitian telah membuktikan bahwa kombinasi terapi memberikan efek lebih baik untuk menurunkan suhu, tetapi untuk saat ini belum dapat direkomendasikan untuk praktik sehari-hari dikarenakan kurangnya bukti/studi yang cukup kuat terhadap outcome klinis anak secara keseluruhan terutama tingkat keamanannya, karena metode ini cukup berisiko membingungkan orangtua sehingga dapat terjadi kesalahan pemberian dosis obat yang akan meningkatkan risiko toksisitas obat. ${ }^{4,10,11}$

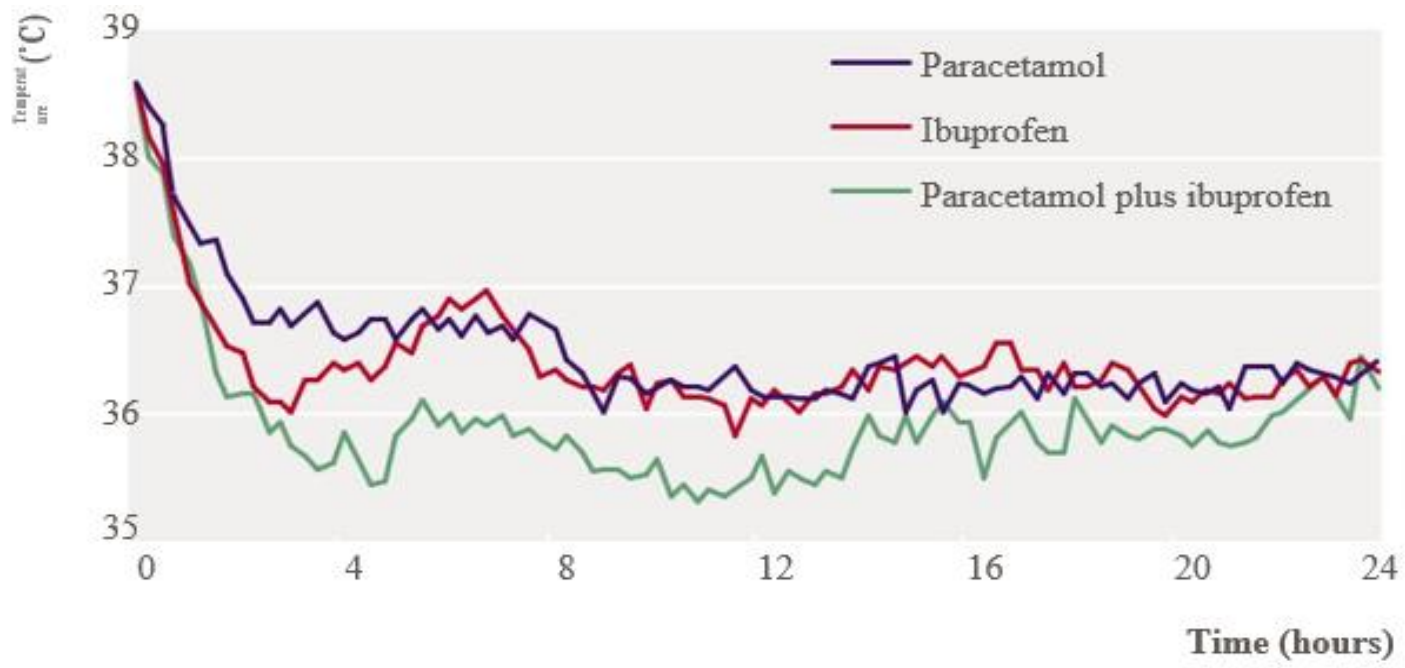

Gambar 3. Perbandingan Efek Penurunan Suhu dari Berbagai Metode Pemberian Antipiretik ${ }^{10}$

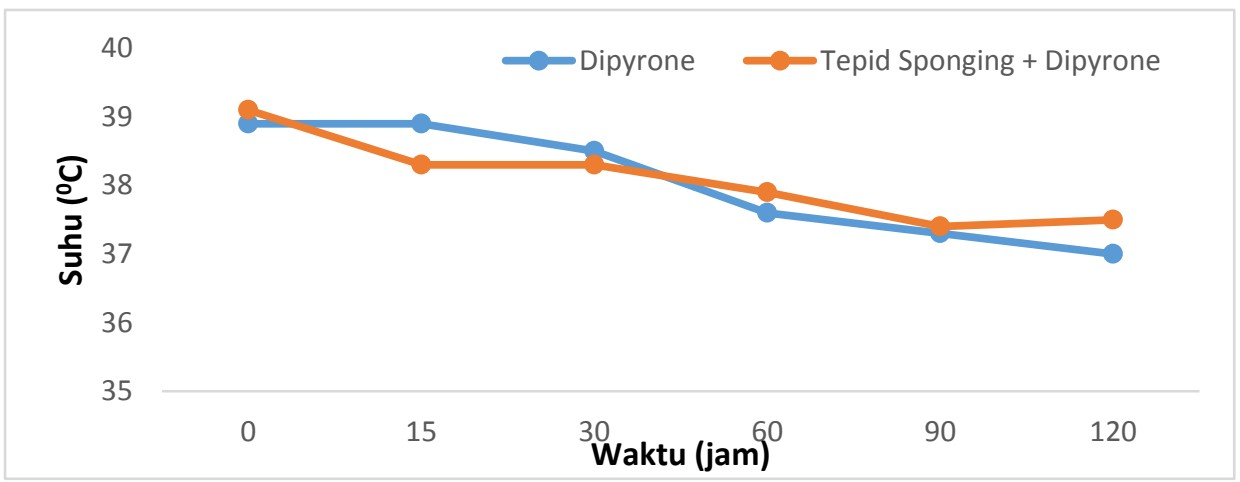

Gambar 4. Perbandingan Penggunaan Dipyrone dengan Dipyrone+Tepid Sponging ${ }^{14}$ 
Tabel 3. Perbandingan Penurunan Suhu dengan Berbagai Metode Pemberian Antipiretik ${ }^{11}$

\begin{tabular}{|c|c|c|c|c|}
\hline Temperature & $\begin{array}{l}\text { Ibuprofen Alone } \\
\qquad(\mathrm{n}=20)\end{array}$ & $\begin{array}{l}\text { Ibuprofen }+ \\
\text { Acetaminophen } \\
(n=20)\end{array}$ & $\begin{array}{l}\text { Ibuprofen Followed by } \\
\text { Acetaminophen } \\
(n=20)\end{array}$ & $p^{* t}$ \\
\hline \multicolumn{5}{|l|}{ Hour 0 (baseline) } \\
\hline${ }^{\circ} \mathrm{C}$, mean $(\mathrm{SD})$ & $38.8(0.9)$ & $38.6(0.4)$ & $38.7(0.9)$ & 0.60 \\
\hline$<38.0^{\circ} \mathrm{C}$, no. $(\%)$ & $0(0)$ & $0(0)$ & $0(0)$ & - \\
\hline \multicolumn{5}{|l|}{ Hour 1} \\
\hline${ }^{\circ} \mathrm{C}$, mean (SD) & $37.6(0.5)$ & $37.4(0.5)$ & $37.6(0.4)$ & 0.57 \\
\hline$<38.0^{\circ} \mathrm{C}$, no. (\%) & $16(80)$ & $18(90)$ & $16(80)$ & 0.75 \\
\hline \multicolumn{5}{|l|}{ Hour 2} \\
\hline${ }^{\circ} \mathrm{C}$, mean (SD) & $37.1(0.4)$ & $37.0(0.5)$ & $37.2(0.3)$ & 0.52 \\
\hline$<38.0^{\circ} \mathrm{C}$, no. (\%) & $19(95)$ & $20(100)$ & $20(100)$ & 1.00 \\
\hline \multicolumn{5}{|l|}{ Hour 3} \\
\hline${ }^{\circ} \mathrm{C}$, mean $(\mathrm{SD})$ & $37.2(0.6)$ & $36.9(0.4)$ & $36.9(0.4)$ & 0.20 \\
\hline$<38.0^{\circ} \mathrm{C}$, no. (\%) & $18(90)$ & $20(100)$ & $20(100)$ & 0.32 \\
\hline \multicolumn{5}{|l|}{ Hour 4} \\
\hline${ }^{\circ} \mathrm{C}$, mean (SD) & $37.5(1.1)$ & $36.9(0.3)$ & $36.9(0.3)$ & 0.002 \\
\hline$<38.0^{\circ} \mathrm{C}$, no. (\%) & $14(70)$ & $20(100)$ & $20(100)$ & 0.002 \\
\hline \multicolumn{5}{|l|}{ Hour 5} \\
\hline${ }^{\circ} \mathrm{C}$, mean (SD) & $38.0(1.1)$ & $36.9(0.5)$ & $36.8(0.3)$ & $<0.001$ \\
\hline$<38.0^{\circ} \mathrm{C}$, no. (\%) & $12(60)$ & $20(100)$ & $20(100)$ & $<0.001$ \\
\hline \multicolumn{5}{|l|}{ Hour 6} \\
\hline${ }^{\circ} \mathrm{C}$, mean (SD) & $38.5(1.5)$ & $37.2(0.6)$ & $36.9(0.3)$ & $<0.001$ \\
\hline$<38.0^{\circ} \mathrm{C}$, no. $(\%)$ & $10(50)$ & $19(95)$ & $20(100)$ & $<0.001$ \\
\hline
\end{tabular}

\section{Terapi Non Farmakologis}

Terapi secara fisik seperti tepid sponge dilakukan dengan cara memberikan kompres air suam kuku $\left(32-35^{\circ} \mathrm{C}\right)$ di lipat ketiak dan lipat selangkangan selama 10-15 menit. Tindakan ini akan membantu menurunkan panas dengan cara mengeluarkan panas tubuh melewati pori-pori kulit melalui proses penguapan. ${ }^{4,12}$

Pada beberapa penelitian, didapatkan bahwa penggunaan kompres hanya efektif dalam 15-30 menit pertama. Kompres tidak dianjurkan untuk menjadi terapi utama penurun demam pada anak karena hanya menurunkan panas melalui evaporasi dari permukaan tubuh, tetapi tidak memberi efek pada pusat termoregulasi. ${ }^{13}$

Kompres alkohol bukanlah suatu metode yang direkomendasikan karena ada beberapa kasus yang mencatat adanya penyerapan sistemik dari alkohol. Upaya untuk mengurangi penggunaan pakaian atau memberikan pakaian secara berlebihan pada anak yang demam juga tidak dianjurkan. ${ }^{1,13}$

Kompres dingin juga tidak direkomendasikan untuk mengatasi demam karena dapat meningkatkan pusat pengatur suhu hipotalamus, mengakibatkan badan menggigil sehingga terjadi kenaikan suhu tubuh. Kompres dingin mengakibatkan vasokonstriksi, yang pada akhirnya akan meningkatkan suhu tubuh. Selain itu, tindakan ini dapat membuat anak merasa tidak nyaman. ${ }^{12}$

Terapi fisik lainnya dapat berupa tirah baring. Aktivitas yang tinggi dapat meningkatkan suhu tubuh anak dengan demam dan tanpa demam. Walaupun demikian, pergerakan anak yang demam selama aktivitas normal tidak cukup menyebabkan demam. Memaksakan anak yang sedang demam untuk tirah baring terbukti kurang efektif, menimbulkan ketidaknyamanan, dan mengganggu secara psikologis. Suatu penelitian kasus-kontrol dari 1082 anak dengan demam menunjukkan bahwa tirah baring tidak menurunkan suhu secara signifikan. ${ }^{12}$

\section{Diskusi}

Dari berbagai studi yang sudah dilakukan di berbagai tempat dapat disimpulkan bahwa 
penggunaan antipiretik tetap menjadi yang terutama. Penggunaan antipiretik baik parasetamol maupun ibuprofen sudah teruji secara klinis efektif, apapun cara pemberiannya baik secara kombinasi, bergantian, maupun pemberian single agent baik itu parasetamol saja ataupun ibuprofen saja. Beberapa studi juga mengatakan bahwa penggunaan ibuprofen bersamaan dengan parasetamol, maupun pemberiannya secara bergantian memiliki efek antipiresis yang lebih signifikan dan konsisten, tetapi untuk keamanan belum teruji. ${ }^{9-11,14}$

Pemberian parasetamol dan ibuprofen dapat menurunkan demam dalam kisaran waktu sekitar 30 menit. Penggunaan antipiretik lain juga dilaporkan di beberapa studi seperti penggunaan ketoprofen dan dipyrone (metamizole), juga terbukti efektif dalam menurunkan demam. Studi Alves et al di Brazil melaporkan penggunan dipyrone dapat menurunkan demam sama efektifnya dengan antipiretik lain (lihat gambar 4). Studi Kokki di Finlandia juga menyimpulkan bahwa penggunaan ketoprofen $0,5 \mathrm{mg} / \mathrm{kg}$ memiliki efikasi yang sama dengan penggunaan parasetamol ataupun ibuprofen, dan juga tidak ditemukan adanya efek samping yang bermakna. ${ }^{9-11,14}$

Metode kombinasi antipiretik maupun kombinasi bergantian antara parasetamol dan ibuprofen memang memberikan efek antipiretik yang lebih signifikan, akan tetapi beberapa studi dan rekomendasi tidak menganjurkan metode ini karena rentan terjadi kesalahan dalam pemberian dosis obat dan dapat meningkatkan risiko toksisitas obat. Selain itu, belum ada bukti kuat kalau metode kombinasi akan meningkatkan outcome anak dengan demam secara keseluruhan dan belum teruji keamanannya. ${ }^{1,2,10}$

Upaya untuk mengurangi demam dapat juga didukung dengan penggunaan antipiretik ditambah kompres hangat (tepid sponging). Telah dilakukan studi perbandingan antara pemberian antipiretik saja, pemberian kompres saja, maupun kombinasi kompres dengan antipiretik. Studi Alves et al menunjukkan bahwa metode kompres hangat ditambah dengan penggunaan dipyrone akan menurunkan demam terutama pada 15 menit pertama (lihat gambar 4). Pada studi tersebut, penggunaan antipiretik ditambah dengan kompres hangat terbukti lebih efektif dibandingkan dengan penggunaan antipiretik saja. Beberapa studi lain juga menyatakan hasil yang sama terutama untuk 30 menit pertama. Bahkan, kompres hangat ini direkomendasikan terutama untuk anak yang memiliki risiko untuk terjadinya kejang demam. ${ }^{13,15}$

\section{Simpulan}

Demam merupakan gejala klinis pada anak yang paling sering ditemukan di fasilitas kesehatan. Kurangnya pengetahuan orangtua tentang penanganan demam pada anak cenderung menyebabkan kurang tepatnya pemberian obat-obatan antipiretik.

Pemberian parasetamol atau ibuprofen sudah terbukti efektif dan aman untuk penanganan demam pada anak apabila diberikan sesuai dosis rekomendasi. Penggunaan kombinasi bergantian antara parasetamol dan ibuprofen belum dapat direkomendasikan karena rentan terjadi kesalahan dalam pemberian dosis dan meningkatkan risiko toksisitas obat, walaupun menunjukkan efek antipiretik yang lebih signifikan.

Pemberian kompres hangat (tepid sponging) sudah teruji efektivitasnya untuk menurunkan demam pada anak apabila dibarengi dengan pemberian antipiretik dengan dosis yang sesuai. Tetapi perlu diingat, terapi kompres tidak direkomendasikan sebagai terapi tunggal untuk menurunkan demam pada anak karena hanya membantu menurunkan panas melalui evaporasi dan tidak berefek langsung pada pusat termoregulasi.

\section{Daftar Pustaka}

1. American Academy of Pediatrics. Clinical report - fever and antipyretic use in children. Pediatrics. 2011;127:580-7.

2. Chiappini E, Principi N, Longhi R, Tovo $\mathrm{PA}$, Becherucci $\mathrm{P}$, Bonsignori $\mathrm{F}$, et al. Management of fever in children: Summary of the Italian Pediatric Society guidelines. Clin Ther. 2009; 31: 1826-43.

3. Peetoom KK, Ploum LJ, Smits JJ, Halbach NS, Dinant GJ, Cals JW. Childhood fever in well-child clinics: a focus group study among doctors and nurses. BMC Health Services Research. 2016; 16:240.

4. Barbi E, Marzuillo P, Neri E, Naviglio S, Krauss BS. Fever in children: pearls and pitfalls. Children 2017; 4: 81. 
5. IDAI. Buku ajar infeksi dan pediatri tropis edisi kedua. Jakarta: IDAI. 2015; 21-46.

6. Canadian Paediatric Society. Temperature measurement in paediatrics. Canadian Paediatric Society: 2017.

7. Nizet V, Vinci RJ, Lovejoy FH. Fever in children. Pediatrics in Review 1994; 15; 127.

8. Temple AR, Temple BR, Kuffner EK. Dosing and antipyretic efficacy of oral acetaminophen in children. Clin Ther. 2013; 32: 1361-75.

9. Paramba FC, Naushad VA, Purayil N, Mohammed $\mathrm{OH}$, Chandra P. Randomized controlled study of the antipyretic efficacy of oral paracetamol, intravenous paracetamol, and intramuscular diclofenac in patients presenting with fever to the emergency department. Therapeutics and Clinical Risk Management 2013;9: 371-6.

10. Hay AD, Costelloe C, Redmond NM, Montgomery AA, Fletcher M, Hollinghurst $\mathrm{S}$, et al..Paracetamol plus ibuprofen for the treatment of fever in children (PITCH): randomised controlled trial. BMJ 2008;337:a1302.
11. Paul IM, Sturgis SA, Yang C, Engle L, Watts H, Berlin CM. Efficacy of standard doses of ibuprofen alone, alternating, and combined with acetaminophen for the treatment of febrile children. Clin Ther. 2010; 32: 2433-9.

12. Karyanti MR. Penanganan demam pada anak. IDAI: 2014.

13. Aluka TM, Gyuse AN, Udonwa NE, Asibong UE, Meremikwu MM, Oyo-ita A. Comparison of cold water sponging dan acetaminophen in control of fever among children attending a tertiary hospital in south nigeria. J Family Med Prim Care. 2(2): 153-8.

14. Kokki $\mathrm{H}$ and Kokki M. Ketoprofen versus paracetamol (acetaminophen) or ibuprofen in the management of fever. Clin Drug Investig. 2010; 30 (6).

15. Alves JG, Almeida ND, Almeida CD. Tepid sponging plus dipyrone versus dipyrone alone for reducing body temperature in febrile children. Sao Paulo Med J. 2008;126(2):107-11. 